\title{
"Lord Save Us from Champions like This": The Sonny Liston- Muhammad Ali Heavyweight Championship Bouts as Transnational Sporting Culture in 1960s Finland ${ }^{1}$
}

\section{Benita Heiskanen}

University of Turku

\section{Hannu Salmi}

University of Turku

\begin{abstract}
The two championship bouts between Sonny Liston and Muhammad Ali in 1964 and 1965 are among some of the most controversial events in the history of boxing. While their significance has been interpreted in the United States against the backdrop of the Civil Rights era, this article opens up a pathway for discussing transnational meanings and functions that African American heavyweight champions assumed in faraway lands, such as Finland. Contextualized within a Transnational American Studies research paradigm, the article considers the multiple ways in which Finnish media reporting made sense of and imposed significance on transnational sporting culture in the 1960s. The article argues that prizefighting served as a lens through which reporters negotiated Euro-American relations, national identity, and
\end{abstract}

1 This paper was originally written for the symposium "Ali in Un/Expected Spaces," organized by the John Morton Center for North American Studies at the University of Turku, Finland on May 17-19, 2017. All translations from Finnish to English in this article are by Benita Heiskanen. We would like to express thanks to the anonymous reviewers as well as members of the JMC Research Network for comments on earlier drafts of this paper. Thanks also to Albion M. Butters for proofreading the text. 
the global spread of professional sports at the expense of amateurism. In addition to providing a site for negotiating ethnic and racial differentiation, the primary sources analyzed show the ways in which prizefighting offered a locus for constructing performative, class-based sporting whiteness.

Keywords: boxing, heavyweight champions, Muhammad Ali, Sonny Liston, Transnational American Studies, sport, race, Finland, United States

\section{Introduction}

On February 25, 1964, on the day of the first world championship encounter between the reigning heavyweight Charles "Sonny" Liston and Cassius Marcellus Clay - later known as Muhammad Ali-in Miami Beach, Florida, the Helsingin Sanomat claimed that the challenger's only chance was to bring a cannon into the ring. ${ }^{2}$ So certain was Finland's largest newspaper about the outcome that it declared: "Only the round is up for debate."3 Two days later, after Ali's upset victory, the paper did not mince words in describing the new titleholder: "Lord save us from champions like this, loudmouth creeps of the ring." Muhammad Ali's notoriously unorthodox style and verbal braggadocio panned by the technically savvy Finnish fight scribes, who closely followed U.S. media discourses and controlled the sporting narrative in Finland. Finnish reporters were extremely knowledgeable of prizefight history, contemporary debates about boxing globally, and events and incidents preceding championship bouts. Moreover, being well aware of fighters' images, statements, and publicity stunts, they took cues from and participated in global discourses on boxing. Yet the sentiments attached to and channeled through heavyweight champions exemplified not only the reporters' personal opinions but also some broader concerns that they held about Euro-American affairs and the global spread of professional sports at the expense of amateurism.

This article's discussion is contextualized within a Transnational American Studies research paradigm that moves beyond studying U.S. influence within its geographic boundaries, with a particular focus on

2 For the sake of simplicity, this article will use the name Muhammad Ali throughout, even though he only assumed the new name after his first encounter with Liston.

3 "Ensi yönä paukahtaa Miami Beachin MM-kehässä. Listonin tyrmäysvoittoa pidetään täysin varmana. Vain erästä kiistellään," Helsingin Sanomat, February 25, 1962, p. 22.

4 M.S., "Se suuri ottelu," Helsingin Sanomat, February 27, 1962, p. 17. 
transnational racial formation in media reporting of boxing. While Transnational American Studies did not become prominent until the turn of the twenty-first century, the article demonstrates the multiple ways in which transnationalism assumed meaning through sport much earlier than it turned into a scholarly focus within the field. ${ }^{5}$ The article brings an important addition to the field; even as existing scholarship has problematized the nature of transnationalism in American Studies research on a theoretical level, in practice, work conducted by scholars within the school of thought has centered on the United States. ${ }^{6}$ By decentering the United States in discussing the influence of prominent heavyweight champions, this article underscores the discussion of race and sport as issues that have widespread resonance beyond national boundaries. ${ }^{7}$ The transnational optic does not mean rejecting the importance of the nation-state in discussion of key questions, such as racial formation, or the relevance of national power relations; rather, it means decentering them-exploring the question of race and sport from new spatial perspectives. ${ }^{8}$ Through the transnational lens, the article exemplifies the ways in which national media discourses of racial formation - through sport and popular culture at large - are useful in explicating broader configurations of social power relations.

5 For twenty-first century discussions of transnationalism in American Studies, see Laura Briggs, Gladys McCormac, and J.T. Way, "Transnationalism: A Category of Analysis," American Quarterly 60 (September 2008): 625-648; Shelley Fisher Fishkin, "Crossroads of Cultures: The Transnational Turn in American Studies-Presidential Address to the American Studies Association," American Quarterly 57 (March 2005): 17-57; Benita Heiskanen, "Where Are 'We' in Transnational U.S. Latino/a Studies?" Diálogos Latinoamericanos 16 (2009): 5-15; Joel Pfister, “Transnational American Studies for What?" Comparative American Studies 6:1 (July 2013): 13-36.

6 For example, Winfried Fluck, Donald E. Pease, and Carlos Rowe's Re-Framing the Transnational Turn in American Studies, which features essays dealing with transnational influences, has only one essay that is not geographically situated inside the boundaries of the United States. See Winfried Fluck, Donald E. Pease, and John Carlos Rowe, eds. Re-Framing the Transnational Turn in American Studies (Hanover, NH: Dartmouth College Press, 2011).

7 For transnational discussions of sport beyond boxing, see Souvik Naha, "Over the Border and the Gates"? Global and Transnational Sport, Sport in Society 20:10 (2017): 1347-1353 and Richard Giulianotti and Roland Robertson, "Sport and Globalization: Transnational Dimensions," Global Networks 7:2 (2007), 107-112.

8 While there is no prior research on the transnational aspects of boxing, US-European transnationalism has been discussed through other sporting discourses. See Souvik Naha, “'The Russian Deadpan Expert' vs 'America's White Hope": The Personal, the National, and the Global in the 'Cold War' of Chess," Philippe Vonnard et al, Beyond Boycotts: Sport During the Cold War in Europe (Berlin: De Gruyter Oldenbourg), 2018; Ulf Jonas Björk, “AAn NHL Touch': Transnationalizing Ice Hockey in Sweden, 1994-2013,” Journal of Transnational American Studies, Special Forum 7:1 (2016); and Maija Urponen, "Ylirajaisia suhteita : Helsingin olympialaiset, Armi Kuusela ja ylikansallinen historia," Ph.D. dissertation., University of Helsinki, 2010. 
The two championship bouts between Liston and Ali in 1964 and 1965complete with upsets, intrigue, and unsubstantiated rumors-comprise some of the most controversial events in the history of boxing. ${ }^{9}$ The first meeting was marred by a debacle about an unlawful substance on Liston's gloves, which blinded Ali in the fifth round, and Liston's subsequent failure to answer the bell in the seventh round. The second bout became infamous due to Ali's so-called "phantom" or "anchor" punch in the first round, followed by cries of foul play; controversy surrounding the decision remains among boxing cognoscenti to the present day. ${ }^{10}$ Both the matches and the champions enjoyed wide visibility and a broad following in Finland, demonstrating the intensity with which heavyweight champions' fame and notoriety traveled around the world. While the historical significance of the Liston-Ali bouts has been primarily interpreted in the United States against the backdrop of the Civil Rights era, this article opens up a pathway for discussing transnational meanings and functions that African American heavyweight champions assumed in faraway lands, such as Finland. ${ }^{11}$

This article considers the multiple ways in which Finnish media reporting made sense of and imposed significance on transnational sporting culture within the sociohistorical context of 1960s Finland. As a rather isolated country between Sweden and the then-Soviet Union, Finland provides a noteworthy case for empirical analysis of discussion of boxing in the media. We draw from newspaper reporting from various regions in Finland-both national papers in Finnish and Swedish from the capital city and provincial newspapers from across the country - within a span of two weeks before and after the bouts. We focus on print media, in which reporting of the bouts was widespread throughout the nation, thus offering a particularly relevant lens for the discussion of racialization. Television was an emerging new medium in the early-1960s Finland, but it was still

9 See Bob Mee, Ali and Liston: The Boy Who Would Be King and the Ugly Bear (New York: Skyhorse Publishing, 2011); José Torres and Bert Randolph Sugar, Sting Like a Bee: The Muhammad Ali Story (New York: Curtis Books, 1971); Nich Tosches, The Devil and Sonny Liston (Boston: Little, Brown and Company, 2000).

10 For the controversy, see Timothy Hackman, "A Blues Song Just for Fighters: The Legend of Sonny Liston." Aethlon, 27:2 (2010): 1-22.

11 Michael Ezra, Muhammad Ali: The Making of an Icon (Philadelphia: Temple University Press, 2009); David Remnick, King of the World (New York, Vintage Books, 1998); Kasia Boddy, "Liston and Ali: the Ugly Bear and the Boy Who Would Be King by Bob Mee: review." The Telegraph, August 162010 , https://www.telegraph.co.uk/culture/books/bookreviews/7940651/Liston-and-Ali-the-UglyBear-and-theBoy-WhoWould-Be-King-by-Bob-Mee-review.html. 
geographically limited; therefore, print media offers a more comprehensive and polyphonic approach to the Finnish culture and society of the time. We have also studied popular magazine coverage, which provides a somewhat more sensationalist approach than newspapers, in the year of each fight. The article first contextualizes the Finnish sporting culture of the 1960s in relation to the landscape of ethnic and racial relations nationally; we then offer a detailed depiction of the ways in which each of the bouts, complete with their dramatic arcs, was discussed in Finland; and finally, we discuss the ramifications that these events had on the understanding of transnational sporting culture. In light of the Finnish reportage examined, we argue that central to the 1960s transnational sporting culture were various racialization processes in which prizefighting not only became a site for negotiating ethnic and racial differentiation but it also offered a locus for constructing performative, class-based sporting whiteness. Based on the print media discussions of the 1960s, Finnish boxing reporting revealed a striking preoccupation with race, serving as a discourse through which Euro-American relations, national identity, and the broader functions of sports were addressed. Ultimately, the article makes the case that Finnish boxing reporting was a means to negotiate a nostalgia for an earlier period of boxing that boasted the supremacy of white, Nordic sporting prowess.

\section{Legacies of Racial and Spatial Demarcations in 1960s Finland}

At the time of the first Ali/Liston bout, Finland was only 47 years old as an independent nation. Having previously been under Swedish rule from the Middle Ages to the early nineteenth century, Finland was an autonomous Grand Duchy of the Russian Empire from 1809 to its independence in 1917. In 1964, many Finns still were still grappling with memories from the struggle for independence and the Civil War between the Reds and the Whites in 1918. During World War II, Finland fought first against the Soviet Union in the Winter War in 1939-1940 and the so-called Continuation War in 1941-1944, and then against Germany in the War of Lapland in 1944-1945. During those turbulent times, sport was often viewed from the perspective of military capability as well as a means to foster national unity and a sense of belonging, which came to stand for nostalgic notions of 
determination, masculinity, and a particular sense of Nordic strength. ${ }^{12}$ In the early twentieth century, wrestling and long-distance running, both regarded as masculine sporting practices, were particularly popular in Finland. In the 1920s, the runner Paavo Nurmi, also known as "The Flying Finn," won nine Olympic Gold Medals and became a worldwide celebrity. In the early 1930s, Nurmi turned professional, a decision that was fiercely debated in Finland. In public discussions, professionalism was strongly criticized; this reflected a widespread attitude in Finnish sporting culture that favored the ideal of amateurism. ${ }^{13}$ Unlike in the United States, where, to cite Gerald Early, sport was premised on the values of a monopolistic, laissez-faire capitalism, in Finland the influence of money in sport was abhorred. ${ }^{14}$ This belief was prominent for decades and impacted the ways in which professional boxing in general and the Ali/Liston bouts, in particular, were interpreted in Finland. Another point to consider by way of background is that Finnish sporting culture had been sharply divided politically ever since the end of the Civil War in the early twentieth century. Wrestling and boxing were considered to be working-class diversions and had a widespread following in the country. When charismatic U.S. heavyweights were broadcast on Finnish television, they were an easy sell for Finnish audiences, who already had a strong tradition in combat sports. ${ }^{15}$

Although relatively isolated during the World War II period, Finland re-emerged on the international amateur sporting map during the Helsinki Olympics in 1952, around the same time that the rest of Finnish society began modernizing. After the Civil War of 1918, sports in Finland had been divided into two separate factions: the Finnish Workers' Athletic Federation

12 Erkki Vasara, "Maintaining a Military Capability: The Finnish Home Guard, European Fashion and Sport for War," in Henrik Meinander and J.A. Mangan, eds. The Nordic World: Sport in Society (London: Frank Cass), 157-172. The position of wrestling and long-distance running was established already at the time of Russian rule. The most legendary sports act was the almost twelve-hour fight between the Finnish and the Russian wrestlers at the Stockholm Olympics in 1912, where Finland could participate under its own flag for the first time.

13 Per Jørgensen, "From Balck to Nurmi: The Olympic Movement and the Nordic Nations," in Henrik Meinander and J.A. Mangan, eds. The Nordic World: Sport in Society (London: Frank Cass), 47-68; Paavo Karikko \& Mauno Saari, Legendary Runner: A Biography of Paavo Nurmi (Helsinki: The Sports Museum Foundation of Finland, 2006).

14 Gerald Early, "Baseball, Boxing, and the Charisma of Sport and Race," in Louis Wacquant et al., eds., The Charisma of Race and Sport, Doreen B. Townsend Center Occasional Papers 8 (1996): 1-9.

15 Ilmo Lounasheimo \& Atle Salokangas, Kehän ääreltä: 70 v. suomalaista nyrkkeilyä (Helsinki: Suomen nyrkkeilyliitto, 1994). 
(Työväen Urheiluliitto, TUL) and the Finnish State Athletic Federation (Suomen Valtakunnan Urheiluliitto, SVUL). Upon the founding of the International Boxing Association (Association Internationale de Boxe Amateur, AIBA) in 1964, the Finnish Boxing Federation was a member of SVUL, but individual boxing clubs were members of both federations, resulting in frequent tensions around who got to represent the nation in international tournaments. Finnish fighters had achieved a measure of success in European prize rings since the 1930s, with some stars-like the heavyweight Gunnar Bärlund, lightweight Elis Ask, lightweight Olli Mäki, and bantamweight Risto Luukkonen - ranked as top contenders in world championship boxing. ${ }^{16}$

Although there had been racialized minorities (such as the Roma) and indigenous people (the Sámi) in the country for centuries, Finnish society was considered to be conspicuously homogeneous and there was little recognition, much less discussion, of ethnic/racial consciousness domestically. ${ }^{17}$ As various scholars of the Nordic region have pointed out, the characterization of Finland and Finns assumed a curious position of ambiguity at the margins of "Europeanness," between the East and the West. ${ }^{18}$ Drawing on a plethora of existing scholarship, Johanna Leinonen demonstrates the ways in which Finnishness itself has been typically defined as being "between Sweden and Russia." ${ }^{19}$ In early pseudoscientific racial theorization of the nineteenth and early twentieth centuries, Finns were categorized as being of "Mongol origins" and part of an Asian racial lineage.${ }^{20}$ According to Maija Urponen, the categorization of Finns among

16 "Suomen kaikkien aikojen TOP 10," Boxing.fi, December 30, 2016, accessed January 21, 2019, http:// boxing.fi/suomen-kaikkien-aikojen-top-10/4/.

17 Discussions of ethnic consciousness of the Sámi became stronger at the turn of the 1970s. See Niina Siivikko, "Kaikuja Saamenmaalta. Saamelaiskysymys suomalaismediassa 1971," MA thesis, University of Turku, 2015, 16-17.

18 See Kristín Loftsdóttir \& Lars Jensen, Whiteness and Postcolonialism in the Nordic Region: Exceptionalism, Migrant Others and National Identities (London: Routledge, 2012) and Suvi Keskinen, Salla Tuori, Sara Irni, and Diana Mulinari, eds., Complying with Colonialism: Gender, Race and Ethnicity in the Nordic Region (London: Routledge, 2009).

19 Johanna Leinonen, "Hierarchies of Desirability: Racialized Cartographies in Media Discourses on Relationships between Finns and Foreigners (1982-1992)," Scandinavian Studies, 89:2 (Summer 2017): 217-239.

20 Suvi Keskinen, "Intra-Nordic Differences, Colonial/Racial Histories, and National Narratives: Rewriting Finnish History," Scandinavian Studies, 91: 1-2 (Spring/Summer 2019), 163-181. For further details, see also Aira Kemiläinen, Suomalaiset, outo Pohjolan kansa: Rotuteoriat ja kansallinen identiteetti (Helsinki: Finnish Historical Society, 1993). 
the "Eastern races" rather than the "race nordique"-akin to Sweden, Norway, and Denmark - was a sensitive issue for Finnish elites up until the mid-twentieth century. ${ }^{21}$ According to Urponen, such ideas also informed media discourses of Finnishness and "Otherness." Notwithstanding such ambiguity, Suvi Keskinen has made the case that Finnish racialized attitudes should be conceptualized as part of the broader attitudes of the Nordic region..$^{22}$ Keskinen argues that while the Nordic countries were not in possession of many overseas colonies, they were nevertheless intertwined with European colonial practices "through multiple economic, political, cultural, and knowledge-production processes., ${ }^{23}$ This article, too, similarly considers the Finnish sporting reporting as part of the Nordic region, in order to better make sense of the racialized and class-based attitudes that shaped the reception of the two Liston/Ali bouts. In practice, Finnish newspapers collaborated with Swedish reporters in particular, whose reporting on the bouts was translated and distributed widely in Finland.

\section{"A Shock to Every Pugilistic Prophet": The First Bout}

Boxing was a natural fit for television and enjoyed the new technology of televised sports in Finland. An amateur tournament between Finland and Sweden was televised live from the Messukeskus arena in Helsinki already in 1958. By the time of the Liston-Ali bouts, boxing had an extensive following in Finland. ${ }^{24}$ Both bouts were shown on TV free of charge, the first via a relay satellite an hour after the fight and the second one live, and they were also broadcast over the radio. According to newspaper estimates, a total of 175 million Europeans in Austria, Belgium, Denmark, England, Finland, France, Italy, Norway, Sweden, and West Germany saw the first bout via a TV broadcast. ${ }^{25}$ All eight newspapers under examination in this article reported on the Liston-Ali bouts, with the Turun Sanomat (Turku) having by far the most boxing coverage.$^{26}$ For the first bout in February

21 Maija Urponen, "Ylirajaisia suhteita: Helsingin olympialaiset, Armi Kuusela ja ylikansallinen historia," Ph.D. dissertation, University of Helsinki, 2010, 10.

22 Ibid., 164.

23 Ibid.

24 Lounasheimo \& Salokangas, 9.

25 "MM-ottelu nähdään myös Suomen televisiossa jo varhain keskiviikkoaamuna," Aamulehti, February 23, 1964, p. 7; "MM-ottelusta suora tv-lähetys Suomeen," Turun Sanomat, May 23, 1965, p. 2.

26 In 1964, there were a total of 223 newspapers in Finland; 92 of these appeared more than twice a week, 
1964, for example, the paper trumpeted that it had a correspondent in Miami Beach to cover the fight live, and it advertised a special issue to Finnish readers: "Cassius Clay's sensational knockout explained here punch by punch up until the dramatic end!" 27 While in reality the paper did not have its own correspondent but commissioned the reporting from a Swedish journalist, its claim speaks to the value the paper attached to boxing reporting. The Helsingin Sanomat (Helsinki), on the other hand, did have a Finnish correspondent in Miami. Likewise, the Aamulehti (Tampere) had its own boxing columnist, and it provided the most detailed coverage. The media outside of southern Finland mainly relied on the international news agencies United Press International (UPI), Agence France-Presse (AFP), or Reuters.

According to a poll conducted by UPI, the betting odds were 7-1 in Liston's favor, with 43 out of 46 reporters deeming him a favorite; 13 expected a third-round knockout, while five predicted a first-round $\mathrm{KO}^{28}$ The main headline of the Turun Sanomat gave Clay little chance of winning: "The Bout Likely to End in a Quick Liston KO."29 The paper's other headings echoed the sentiment: "Sonny's Explosive Left Believed to Shut Cassius Clay's Mouth," "Cassius Will Be Railroaded," ${ }^{31}$ and "One Punch and It will Be All Over." 32 The Helsingin Sanomat reporter who suggested that Clay bring a cannon into the ring concluded his prediction with a bold proclamation: "So let us have a good night's sleep and wake up in the wee hours to hear in which round Liston KO'd his opponent. Anything else would be a miracle." ${ }^{33}$ Only the Aamulehti left Clay a sliver of hope a day before the bout: "Nobody in the public has seriously suggested that Clay would stand a chance in the bout - except for Clay himself! But Clay's

25 papers appeared seven days a week. See Veikko Löyttyniemi, "Sanomalehdistön rakenne ja talous 1940-luvulta 1980-luvulle," in Päiviö Tommola, ed., Suomen lehdistön historia 3: Sanomalehdistö sodan murroksesta 1980-luvulle (Kuopio: Kustannuskiila Oy, 1988), 319.

27 “Erikoisnumero kertoo Liston-Clay erä erältä," Turun Sanomat, February 26, 1964, p. 1.

28 “Älkää unohtako: Cassius on nuorempi - nopeampi ja kookkaampi,” Aamulehti, February 24, 1964, p. 12.

29 “Ottelu päättynee Listonin nopeaan tyrmäysvoittoon,” Turun Sanomat, February 25, 1964, p. 12.

30 "Sonnyn räjähtävän koukun uskotaan tukkivan Cassius Clayn suun," Turun Sanomat, February 25, 1964, p. 12.

31 “Cassius jää jyrän alle,” Turun Sanomat, February 25, 1964, p. 12.

32 "Yksi isku ja kaikki on ohi," Turun Sanomat, February 25, 1964, p. 12.

33 M-o-n-i, "Ensi yönä paukahtaa Miami Beachin MM-kehässä. Listonin tyrmäysvoittoa pidetään täysin varmana. Vain erästä kiistellään.” Helsingin Sanomat, February 25, 1964, p. 22. 
victory is by no means impossible." ${ }^{34}$ Cautiously suggesting that Liston's best days may well have been behind him, the Aamulehti called attention to Clay's age, height, and reach advantage as possible keys to a long-shot upset. In addition to standard pre-fight details, such as weight and height, the reporting included measurements of the fighters' ankles, calves, fists, and arms, constructing images of herculean athletes taking measure of each other. Enlightening Finnish readers about boxing techniques, the judges' score cards, and pugilistic history, the reporters described the champion and contender in terms of heavyweight champions dating all the way back to 1883 , the beginning of gloved boxing.

Local sports fans were familiar with the fighters' profiles and had strong opinions about their odds. Before both bouts, the Aamulehti polled passersby from different walks of life. Mrs. Aila Rinne expressed her viewpoint: "It feels like Sonny Liston will win and that it will be an easy victory. He's so much stronger and more experienced." A CEO by the name of Aulis Hirvonen predicted that "Sonny Liston will KO Clay in the second round." Ulla-Maija Salonen, a student, opined firmly: "Liston wins. He won't get a KO victory though; he'll win by decision." Paavo Lehtinen, a manual laborer, also considered that the fight would be an easy victory for the champion: "Sonny Liston is so much stronger, more experienced, and has bigger fists, Clay does not stand a chance." Yet, store assistant Risto Lehtinen was confident enough to express a dissenting viewpoint: "Pundits and the general public seem to think that the stronger Liston will win. I beg to differ, however, and predict Cassius's victory." ${ }^{35}$ Although Liston was the overwhelming favorite among both fight scribes and aficionados, a large bulk of the reporting before and after the bout focused on Ali, who was a household name already after the 1960 Olympics in Rome.

The reactions after the upset victory - marked by Liston's decision not to continue after the sixth round-followed the pre-fight reporting pattern. Most commentators expressed utter disbelief about the outcome, which the Turun Sanomat described as a "shock to every pugilist prophet." Only a few odd writers accepted it. ${ }^{36}$ The Aamulehti offered a couple of possible reasons for the result: either that Liston did not take his opponent seriously and therefore had not properly prepared for the fight, or that Ali's mind games before the fight had gotten to the champion. "Whatever the case may

34 “Älkää unohtako - Cassius on nuorempi, nopeampi ja kookkaampi," Aamulehti, February 24, 1964. p. 12.

35 "Liston vai Clay?" Aamulehti, February 26, 1964, p. 15. The poll was conducted the previous day.

36 "Izvestija vihjailee ennakolta sopimisesta," Turun Sanomat, February 27, 1964, p. 5. 
be," the paper declared, "Liston was a disappointment. He was stiff, slow, and bizarrely helpless." ${ }^{37}$ By contrast, the Aamulehti praised the challenger:

The best part was Cassius Clay's feigning and ducking across the ring, something one rarely sees in a championship bout. His is a skill that is not learned in boxing gyms; rather, it is a sign of a skill that he was born with. Another striking asset that Clay had was the remarkable footwork that came with his defensive style. Did you see how this young man slid under the flurries of the strongman? $?^{38}$

A tape of the bout (available online) shows former heavyweight champion Joe Louis, who served as expert commentator on the original Theater Network Television (TNT) broadcast, proclaiming after the first round that the whole world might be in for a surprise: "Clay completely outclassed Sonny Liston." 39 The fact that people cried foul after the overpowering performance by Ali-even with his vision blurred in the fifth roundspeaks to the pervasiveness of Liston's larger-than-life media image of invincibility. Yet, the most pressing question to Finnish reporters seemed not to be whether the new champion was justified pugilistically as a victor; instead, many focused on how he would comport himself as a champion going forward. The Helsingin Sanomat posed the question as follows: "A whole different matter is whether the winner of the world championship, Cassius Clay, will be a popular champion. Arrogance and braggadocio are not looked upon favorably in the world." ${ }^{\prime 40}$ According to the Turun Sanomat, Clay "most definitely did not look like a champion, but rather the worst kind of a brat, who just managed to kick over an ice cream van without soiling himself." ${ }^{41}$

At the same time, Ali's upset victory was interpreted vis-à-vis a socioeconomic critique of racialized prizefighting in the United States. The Lapin Kansa, the main newspaper of the region of Lapland, viewed the bout through a combination of racial overtones and criticism of the business of boxing:

37 “Jou penkin päästä," Aamulehti, February 27, 1964, p. 14.

38 Ibid.

39 "Sonny Liston vs. Muhammad Ali I," ESPN Classic (Theater Network Television), accessed June 25, 2018, https://www.youtube.com/watch?v=z_fd2WXFWzE.

40 M-o-n-i, "Cassius käytti kaavamaisesti hyväkseen Sonnyn heikkouksia," Helsingin Sanomat, February 27, 1964, p. 17.

41 Sinetti, "Mitä todella tapahtui?" Turun Sanomat, February 28, 1964, p. 12. 
It is utterly strange that when two Negroes fight somewhere in Miami across the Atlantic, we have to wake up from our sweetest dreams at five am to listen to the bout on the radio. And even stranger was the fight whose outcome was unexpected... To understand the bout, one must remember what dictates everything in professional boxing: It is money... [The millionaires financing the bout] are not interested in the sport of boxing, but money. Let us venture a guess that they will soon start organizing a rematch with great fuss. That will generate more money. ${ }^{42}$

The Helsingin Sanomat weighed in on the business practices of prizefighting - and their impact on athletic integrity - on both sides of the Atlantic: "The advantage of European professional boxing is that it is not backed by millionaires and billionaires. It pays prize money, but not for humbug. And that is why it can still be considered sport." ${ }^{43}$ The Kaleva (Oulu) found an ironic twist through which to interpret the bout: "The much vilified Finnish television deserves credit for once. Had the Miami Beach world championship bout been left to the reporting of news agencies, the Finnish people would have had no chance to witness with their own eyes the kind of humbug that the world of professional boxing feeds on." ${ }^{44} \mathrm{Al}-$ though Ali vocally claimed in his post-fight interview that Liston's corner put liniment on the champion's gloves to blind his vision in the fifth round, the accusation was barely picked up by Finnish media. Only the Hufvudstadsbladet, the Swedish-language newspaper in Helsinki, discussed the accusation at any length. ${ }^{45}$

In addition to offering an interesting case to consider the significance of world championship boxing beyond the United States, the Liston-Ali fight serves as a distinct example of what Michael Omi and Howard Winant describe as "racial projects," processes in which racial categories are created, defined, and transformed: "A racial project is simultaneously an interpretation, representation, or explanation of racial dynamics... Racial projects connect what race means in a particular discursive practice and the ways in which both social structures and everyday experiences are racially organized, based upon that meaning." ${ }^{46}$ The particular racial project that becomes evident in light of our sources exemplifies the ways in which

42 “Aika kapinoi," Lapin Kansa, February 27, 1964, p. 1.

43 M.S. "Se suuri ottelu," Helsingin Sanomat, February 27, 1964, p. 17.

44 "Ja sirkus pyörii," Kansan Uutiset, February 28, 1964, p. 8.

45 “Också Machen beskyller Liston för linimentknep," Hufvudstadsbladet, February 29, 1964, p. 13.

46 Michael Omi and Howard Winant, Racial Formation in the United States: From the 1960s to the 1990s (New York: Routledge, 1994), 56. Italics in the original. 
blackness and whiteness are explained and performed in light of the history of heavyweight boxing - and how race permeates the practice of sport, everyday power relations, and media discourses. ${ }^{47}$

Boxing promotions have historically relied on creating antagonisms between fighters, and the main strategy to sell tickets has involved a build-up of ethnic and racial rivalries ${ }^{48}$ With heavyweight matchups, the confrontation between black and white fighters had long been the most appealing selling point to audiences. After the unexpected outcome of the first Liston-Ali bout, the Helsingin Sanomat invoked this age-old hierarchy: "What we need is a white man: a boxer, a sportsman, who is also a champion in his behavior!" 49 The search for a "Great White Hope," which began after the first African American heavyweight champion Jack Johnson defeated Canadian Tommy Burns in Sydney on December 26, 1908, now assumed new meaning in an all-black championship bout..$^{50}$

Already a month before the first bout, the magazine Hymy described the racial spectacle of heavyweight boxing to Finnish readers: "A classic and most titillating setting in the world championship ring has always been the bitter fight between blacks and whites, an eternal racial contest reduced to two boxers in the squared circle. Apart from [the Swedish heavyweight] Ingemar Johansson's brief sojourn on the throne, that place has been ruled by black men, with no change in sight." ${ }^{51}$ The magazine Apu went even further, explicitly promoting scientific racism: "Boxing is traditionally the sport that has enabled Negroes to get a hold of big purses. And so long as there have been black champions, there have been debates about whether the Negro's skull can take bigger punishment than his white opponent." ${ }^{52}$

47 On the history of nineteenth century racial relations in boxing, see Louis Moore, "Race and Boxing in the Nineteenth Century," in Gerald Early, ed., The Cambridge Companion to Boxing (Cambridge: Cambridge University Press) 2019, 59-68.

48 See Benita Heiskanen, The Urban Geography of Boxing: Race, Class, and Gender in the Ring (New York: Routledge, 2012), Chapters 4 \& 5 .

49 M-o-n-i, "Cassius käytti kaavamaisesti hyväkseen Sonnyn heikkouksia," Helsingin Sanomat, February 27, 1964, p. 17.

50 Joseph Dorinson, "Black Heroes in Sport: From Jack Johnson to Muhammad Ali,"Journal of Popular Culture (1997): 31-33, 115-135. See also, Thomas Hietala, The Fight of the Century: Jack Johnson, Joe Louis, and the Struggle for Racial Equality (Armonk, NY: M.E. Sharpe, 2002; Randy Roberts, Papa Jack: Jack Johnson and the Era of White Hopes (New York: The Free Press, 1983); and Theresa Runstedtler, Jack Johnson, Rebel Sojourner: Boxing in the Shadow of the Global Color Line (Berkeley: University of California Press, 2013).

51 “Minä Cassius Marcellus Clay," Hymy 2 (1964): 32-33.

52 “Minä olen rikkain," Ари 39 (1964): 58. On scientific racism, see Robert W. Sussman, The Myth of Race: 
Philip J. Hutchison has argued that mainstream (white) journalists in the United States bought into and portrayed Liston's character in a stereotypical manner by describing his intimidating persona, physical size, and sexual appetite ${ }^{53}$ Such a pattern was evident in Finnish reporting, too, where Liston's physique was often depicted with commentary that mixed "Othering" and racial innuendo: "How good is Liston? The man whose bicep is as thick as his ox-like neck." ${ }^{54}$ Given that the size of a boxer's bicep or fist has no bearing on punching power, such reporting speaks to the racial exoticization of the athletes. Several papers used the explicitly racist term "Neanderthal" in referring to Liston's boxing style. The focus on the champion's alleged "animal-like" characteristics reinforced the image of him as a bestial, less-than-human character, perhaps also signifying the white male reporters' longing for whiteness as physical superiority they were in fear of losing.

\section{"Something Akin to Witchcraft": The Second Bout}

As some of the Finnish fight scribes predicted, no sooner was the first bout over when speculations about a rematch began. Although the preparations for the first meeting were filled with drama and publicity stunts, they paled in comparison with the hype and polemic of the second bout. From the very beginning, everything about the event was steeped in controversy. Originally scheduled to take place on November 16, 1964 in Boston, the bout was rescheduled for May 25, 1965 in Lewiston, Maine due to Ali's sudden need for a hernia operation. Lewiston, a small factory town of 41,000 people, was hardly known as a hub for pugilism, so the choice of location raised eyebrows among boxing cognoscenti. Allegations of corruption ran wild in the media. There were widespread speculations about either mob involvement or death threats from black radicals. ${ }^{55}$ The word on

The Troubling Persistence of an Unscientific Idea (Cambridge, MA: Harvard University Press, 2014), 210-234.

53 Phillip J. Hutchison, "From Bad Buck to White Hope: Journalism and Sonny Liston, 1958-1965." Journal of Sports Media 10:1, (Spring 2015), 119-137.

54 “Kaikki on ohi," Turun Sanomat, February 25, 1964, p. 12.

55 Reed, Ishmael. "The NOI, The Mob, and Sonny Liston," Black Renaissance/Renaissance Noire 15:1 (Spring-Summer 2015), 12-18. 
the street was that Ali's recent falling-out with Malcolm X had resulted in a clash between his followers and those of Elijah Muhammad, whom Ali sided with. Malcolm X's supporters were rumored to be plotting revenge on Ali, whom they thought had implicitly meddled in X's death. Finnish media followed the dramatic arc of the rumor mill step by step, with such headlines as: "Clay in Need of 300 Law Enforcement Back-up," "A6 "Allah's Avengers Trailing Ali. Weapons Confiscated on the Eve of the Bout," $"{ }^{57}$ and "A Million Dollar Insurance for Clay," ${ }^{58}$ with Ali quoted as saying: "I'm not afraid of either pistols or rifles... I am only afraid of God (Allah) and his messengers." 59

The second bout was broadcast via the Early Bird satellite with 14 countries subscribing, including Finland, Sweden, and Denmark; it was also broadcast on the radio. ${ }^{60}$ In comparison to the first fight, the U.S. predictions of the rematch were more favorable toward Ali, with 71 reporters rooting for the champion and 43 giving the bout to Liston. Only six suggested the fight would go the distance, while everybody else predicted a knockout victory ${ }^{61}$ Betting odds in the U.S., however, were almost even, if slightly tilted in Liston's favor. ${ }^{62}$ Former champions, such as Jack Dempsey and George Chuvalo, predicted an Ali victory, while James Braddock gave it to Liston. Jersey Joe Walcott, a former heavyweight titleholder who was curiously chosen at the last minute to serve as referee, was quoted two days before the bout as trusting in Liston "like a rock." ${ }^{63}$ The Finnish media dutifully reported all of these details, presuming their readership to be knowledgeable of the history of boxing and its most famed past champions. Notwithstanding the high profile of the rematch, newspapers reported difficulties in filling the arena. Most of the profits would be made from remote sales, as the fight was broadcast to approximately 600,000 viewers in

56 “Clay tarvitsee 300 poliisin virka-apua,” Turun Sanomat, May 23, 1965, p. 15.

57 “Allahin kostajat Alin kintereillä. Asetakavarikko ottelun aattona," Turun Sanomat, May 25, 1965, p. 18.

58 “Miljoonan dollarin vakuutus Claylle," Turun Sanomat, May 26, 1965, p. 18.

59 “En pelkää pistooleja," Turun Sanomat, May 25, 1965, p. 18.

60 “Aikainen herätys," Turun Sanomat, May 25, 1965, p. 18.

61 "Lehtimiehet ennustajina,” Turun Sanomat, May 26, 1965, p. 18; “'Suurin kaikista' oli yllättävän hermostunut. Showkin jäi vain kevyeksi sormella osoitteluksi," Helsingin Sanomat, May 26, 1965, p. 32.

62 “Clay-Liston ottelun vedonlyönti tasoissa," Helsingin Sanomat, May 25, 1965, p. 29.

63 "Jersey Joe Walcott luottaa Listonin 'neanderthal-tyyliin' kuin vuoreen," Helsingin Sanomat, May 23, 1965 , p. 31. 
258 theaters across the United States.$^{64}$ According to Travis Vogan, closedcircuit broadcasts were "the sport's biggest moneymaker and the principal way marquee fights were consumed from the mid-1950s through the mid1970s." ${ }^{15}$ Although popular in the United States, this type of distribution of boxing matches never took off in Finland.

The predictions of the major newspapers in Finland were split. The Aamulehti asked, "Will Cassius Clay Tame the 'Big, Bad Bear' Again?" Conversely, the Helsingin Sanomat announced "Difficulties for Cassius Clay: Liston Now 'Nimble, Fit, and Completely Numb to Hard Punches." Notwithstanding the outcome of the first bout, the paper touted the raw power of Liston's punch, which makes its target feel like "the horizon swings over." ${ }^{67}$ The Turun Sanomat called attention to the boxers' differing training regimens: "Whereas CLAY does his 7-8 kilometer roadwork boxing, in lieu of speed LISTON relies on his bear-like power." ${ }^{68}$ Throughout the build-up to the bout, the personal characteristics of each fighter were highlighted in order to highlight the enmity between the champion and challenger. A special issue on the Ali-Liston bout by the tabloid Ilta-Sanomat was advertised with the headline "Giants in the Ring: Cassius Clay-Sonny Liston," with the following quotes under each fighter: "Cassius: 'I will crush the Ugly Bear.' Sonny: 'The blows will fly as soon as the gate cracks wide." ${ }_{69}^{9}$ As Timothy Hackman writes, "a good villain and racial confrontation" was a sure bet to increase interest in boxing matches. ${ }^{70}$ Even so, in the back of many reporters' minds was the scandal created by the first bout, as well as the uproar that ensued. To this end, the Helsingin Sanomat forewarned that "should last year's fiasco be repeated, with Liston quitting after six rounds, the entire gate of the bout might be confiscated." 71

64 “'Suurin kaikista’ oli yllättävän hermostunut. Showkin jäi vain kevyeksi sormella osoitteluksi,” Helsingin Sanomat, May 26, 1965, p. 32.

65 For a discussion of closed-circuit boxing broadcasts, see Travis Vogan, "Exhibiting Ali's Super Fights: The Contested Politics and Brief History of Closed-Circuit Boxing Broadcasts," Film History 30:3 (Fall 2018), 1-31.

66 “Cassius Clay vai Sonny Liston?” Aamulehti, May 24, 1965, p. 18; "Vaikeuksia Cassius Claylle. Liston nyt notkea, kunnossa ja täysin tunnoton koville iskuille," Helsingin Sanomat, May 16, 1965, p. 31.

67 Ibid.

68 "CLAY suorittaa 7-8 kilometrin harjoituslenkkinsä nyrkkeillen. LISTON luottaa nopeuden sijaan karhunvoimiinsa," Turun Sanomat, May 21, 1965, p. 17.

69 “Raskaan sarjan jättiläiset kehässä. Cassius Clay-Sonny Liston. Ilta-Sanomat, May 26, 1965, p. 30.

70 Timothy Hackman, “A Blues Song Just for Fighters: The Legend of Sonny Liston.” Aethlon 27:2 (2010), 11.

71 “Clay-Liston ottelun vedonlyönti tasoissa," Helsingin Sanomat, May 25, 1965, p. 29. 
Indeed, it would be a fiasco. Ali's seemingly powerless knockout punch in the first minute of the first round had people crying foul, with Ali himself towering over Liston, yelling "Get up and fight, you bum!" To make matters worse, the referee Jersey Joe Walcott bungled the count after Liston's knockdown, allowing the fighters to continue, even though one of them had already been de jure knocked out. Nat Fleischer, the editor of Ring magazine, allegedly intervened, proclaiming that the timekeeper's score had Liston already knocked out. ${ }^{72}$ The Turun Sanomat did not mince its words in describing the outcome: "Boxing suffered a heavy blow on Wednesday morning, one that will likely take a long time to recover from... This is a sorry new chapter in the history of boxing and a continuation of the decline of the sport that once was regarded so highly." "73 As in their first meeting, where neither of the fighters were particularly highly regarded, in this bout both drew blame for the outcome. As the Turun Sanomat put it, "Neither of the boxers deserve our sympathies, not the jawbone Clay any more than the veteran Liston, who has a rap sheet as long as his boxing record. But to turn the fight into a complete farce, to cheat the paying viewers, and to make Europeans stay awake in the wee hours for something like this - that's a bit too much." 74

Once again, the Aamulehti conducted a street poll of residents of Tampere, this time asking, "Was the fix in?" Mrs. Aili Mäkinen did not believe so, since Clay had seemed so surprised, and Liston incapacitated after the fight. But a student by the name of Pentti Haapala considered the outcome as "most questionable." Lauri Larvila, a chemigraphist, had not seen the bout himself but he could easily imagine a fix: "One could expect something like that. The money circulating in professional boxing across the Atlantic is such that the behind-the-scenes wheeling and dealing is inevitable. Always has, always will be." ${ }^{75}$ Public commentators and boxing insiders were equal-ly torn about the outcome. The Helsingin Sanomat called the result into question, referring to Ali's knockout punch as "something akin to witchcraft" and quoting George Chuvalo's characterization of Ali's victory

72 Remnick, Chapter 15.

73 “Salama," Turun Sanomat, May 27, 1965, p. 18.

74 “Clayn maailmanennätystyrmäys raskas isku koko nyrkkeilylle. Paras ennalta sovittu ottelu tähän mennessä.” Turun Sanomat, May 27, 1965, p. 18.

75 “Oliko ottelu sovittu?" Aamulehti, May 27, 1965, p. 14. 
as a "heavy blow to boxing. The best fix of all time." ${ }^{76}$ Nat Fleischer, the editor of The Ring, who sat ringside and intervened in the count, insisted that the fight was not a fix and crowned the champion "Fighter of the Month." 77

One curious speculation that originated in the U.K. tabloid The Sun held that Liston was not knocked out by a boxing punch but an unlawful and "potentially lethal" karate punch. Drawing on the expert analysis of a renowned Japanese professor, the argument was circulated widely but ultimately debunked by Finnish media. ${ }^{78}$ According to the Helsingin Sanomat, "Even Cassius's own claim that the knockout was administered by Ali through Allah would be more credible" than it being a karate punch. ${ }^{79}$ To this day, there is no conclusive evidence about what happened in the fight. There are those who are adamant in insisting that Liston took a dive, unbeknownst to Ali, while others argue that Ali's punch, though seemingly weak, shook Liston's balance and was completely legitimate. A whole host of other viewpoints take a position somewhere in between. ${ }^{80}$

As evidenced by the examples discussed in this article, Finnish reporting of the Liston-Ali championship bouts offered a forum to participate in, comment upon, and define a lived experience of a transnational sporting culture. The bouts specifically served as sites of racial formation on multiple scales: some expressed fairly neutral racialization of the athletes, others projected personal fascination and exoticization onto them, and still others articulated overt and jaw-dropping racism. The manner in which both Ali and Liston were depicted as distinct threats to the future of the "noble art," evidenced by statements like "Lord save us from champions like this, loudmouth creeps of the ring" (quoted in this article's title), provided a seemingly legitimate reason for white reporters' questioning of black champions' dominance of the heavyweight throne. While Finnish media reporting exoticized black prizefighters, it simultaneously exemplified what David Roediger has described as processes in which the white working class "comes to think

76 “Tällaiset ottelut eivät nosta ammattinyrkkeilyä entiselle tasolle," Helsingin Sanomat, May 27, 1965, p. 25 .

77 "The Ring nimesi Clayn kuukauden nyrkkeilijäksi. Väitteet sopuottelusta naurettavia," Turun Sanomat, June 3, 1965, p. 14.

78 “Aikainen herätys," Turun Sanomat, May 25, 1965, p. 18.

79 "Clayn kohutulla tyrmäysiskulla ei mitään tekemistä karaten kanssa. Selitys Allahistakin luotettavampi," Helsingin Sanomat, June 1, 1965, p. 21.

80 Paul Gallender, Sonny Liston: The Real Story behind the Ali-Liston Fights (Pacific Grove, CA: CreateSpace Independent Publishing Platform), 2012. 
of itself and its interests as white." ${ }^{81}$ As Finnishness had historically been equated with whiteness, the portrayal of African American heavyweights at times displayed a distinct sense of "Otherness" or alternatively subtle exoticization, but also outright racism. Some of these discourses assumed distinct meanings as a longing or nostalgia for the whiteness purportedly vanquished by reigning black heavyweight champions and considered lost, not only in the context of the Nordic countries but also in relation to masculine prowess on a shared, transnational level. Thus, Finnish reporting of the boxing matches engaged in constructing class-based blackness in the United States while also projecting shared, class-based white masculinity on the domestic front.

\section{Reflection: Negotiating Transnational Sporting Culture}

The Liston-Ali heavyweight championship bouts became sites for transnational sociocultural processes that served particular purposes in the specific geographic, political, and sociohistorical context of 1960s Finland. The Ali-Liston bouts coincided with the rise of television culture in the country, with nearly half a million Finns possessing viewing licenses, a significant number given that regular broadcasts had only begun in 1957 . National television also contributed to a homogeneous nationhood, which Finland in the 1960s reflected. Up until the 1970s, 90\% of Finns belonged to the Lutheran Church, as opposed to today's 70\%. The number of immigrant and foreign-born citizens remained conspicuously low until the 1980s, when the number of immigrants to the country overtook the number of emigrants leaving Finland.$^{82}$ Although some signs of multiculturalism were underway in the 1920s and 1930s, they ceased as a result of World War II, giving rise to a more closed society than the processes of the earlier decades might otherwise have suggested.

After the war, Finland's focus was on paying war reparations to the Soviet Union, which attempted to assert heavy influence on its smaller neighbor. To exercise their own agency, Finns were increasingly eyeing cultural

81 David Roediger, The Wages of Whiteness: Race, and the Making of the American Working Class (New York: Verso 1991, 2007).

82 Jouni Korkiasaari, "Maahanmuutto ja ulkomaalaiset Suomessa," (Turku: Siirtolaisuusinstituutti), 56, accessed May 30, 2019, http://www.migrationinstitute.fi/files/pdf/ presentation/Maahanmuuton-historia-Suomessa_Jouni-Korkiasaari-2017.pdf. 
influences in the West, most notably West Germany and the United States. ${ }^{83}$ Cultural phenomena-including fashion, popular music, movies, and sports-assumed transnational meaning for the Baby Boomer generation. When Ali won the Olympic gold medal in 1960 in Rome, the generation born in 1947 was only 13 years old; at the time of the first Ali-Liston bout, they were 17. Notwithstanding the homogeneity of 1960s Finland, it is important to note that individuals were knowledgeable about and in dialogue with outside cultural influences. Moreover, modes of transnational knowledge transmission were also taking place on a people-to-people scale, as Nordic media representatives traveled all the way to the United States to report on heavyweight championship bouts. On the basis of the newspaper sources studied for this article, we can ultimately make the case that championship boxing provided a forum for simultaneous, ritualized engagement in a transnational sporting culture.

The media reporting from this period, as well as the interview excerpts, provides a window into the ways in which these transnational engagements were negotiated. The geographic context and capitalism of the United States became sources of differentiation by Finnish media reporters. Because of the valorization of amateurism in all athleticism, including boxing, prizefighting as a capitalist practice led to fierce criticism by Finns. Therefore, Finnish reporters frequently commented upon the discrepancies between Finland and the United States. In criticizing the practices of the prizefighting industry, reporters often resorted to describing Finnish sporting fans as being at the mercy of the United States; for example, they complained of "having to wake up from our sweetest dreams" in the middle of the night to watch boxing, only to be disappointed by the outcome. In some instances, these references were even framed in terms of "Europeans" having to stay awake, reflecting strategic identity affiliations long before Finland became a part of any formal European integration in the 1990s. Some Finnish reporters displayed a sense of shared white masculinity in the Nordic countries, evoking a collective sense of victimization at the hands of the prizefighting industry. Throughout the period under examination,

83 Pertti Joenniemi and Marko Lehti, "The Encounter between the Nordic and the Northern: Torn Apart but Meeting Again?," Marko Lehti and David J. Smith, eds., Post-Cold War Identity Politics: Northern and Baltic Experiences (London: Frank Cass, 2003), 127-154; Henrik Meinander, History of Finland (London: C. Hurst \& Co, 2020), 234-254. See also Malcolm Quantrill, Finnish Architecture and the Modernist Tradition (London: E \& FN Spon, 1995). 
a striking aspect of Finnish reporting was that the Swedish-language newspaper Hufvudstadsbladet assumed a distinct role as a cultural translator of U.S. racial and class dichotomies into the Finnish context. Because of its role as a minority-language newspaper, it was likely more sensitive and attuned to recognizing pertinent issues for ethnic and racial minorities.

Even as the Liston-Ali bouts were used as sites to negotiate blackness and whiteness beyond the sporting context, the boxers themselves were not devoid of agency in delineating their public images. On the contrary, championship boxing offered a magnificent podium for a range of public participation and different identity performances by the athletes. In particular, Ali took the notion of all-black profiling and staging confrontations with his opponents to an entirely new level. In both of his fights against Listonand later against Floyd Patterson, Ernie Terrell, Joe Frazier, and George Foreman-Ali used black-on-black racial slurs to build up the antagonism with his opponent. To describe Sonny Liston, Ali frequently used terms that were pregnant with racist innuendo, such as "the big, ugly bear," "the beast," or "gorilla"; in training camp, he wore a robe with "bear hunting" printed on the back. In the pre-fight promotions, Ali countered a reporter's question about Liston by blurting: "Ain't he ugly? He's too ugly to be the world's champ. The world's champ should be pretty like me!" ${ }^{84}$ Even though many of Ali's statements were playful and tongue-in-cheek, he nevertheless came to epitomize the ways in which fighters are both shaped by and shape existing racial stereotypes.

Although Ali's racialization drew from existing stereotypes, it had little to do with skin color or so-called "phenotype." Rather, his racial rhetoric was based on the class dichotomy between himself and his opponents: "'I'm intelligent. When reporters talk to Joe Louis and Sonny Liston, they ask about 'how good is your left' or 'can you throw a right?' But when they talk to me, they ask, "What do you think of Panama. How are things in V'nam?" ${ }^{85}$ By perpetuating existing stereotypes about Liston and other black fighters, Ali "blackened" his opponents, some of whom were actually lighter in skin tone than he was. Ali's rhetoric thus demonstrates the arbitrary nature of the racial signification of all-black matchups. Just as matchmakers had taken advantage of racialized promotions, Ali consciously appropriated

84 “Muhammad Ali vs. Sonny Liston 20th of 61 - Feb. 1964 - IN THEIR OWN WORDS," ESPN, accessed June 25, 2018, https://www.youtube.com/watch?v=7VK0m7UkbrU.

85 “Clay tillhör Black Muslims," Hufvudstadsbladet, February 28, 1964, 16. 
media publicity for his own purposes: "Where do you think I'd be next week if I didn't know how to shout and holler and make the public take notice? I'd be poor and I'd probably be down in my hometown, washing windows or running an elevator and saying 'yassuh' and 'nawsuh' and knowing my place." ${ }^{\prime 86}$ By taking advantage of and capitalizing on existing racial stereotypes, Ali claimed agency in shaping the matchups and in signifying blackness for his own purposes.

Given the status that the Liston-Ali bouts have in the annals of pugilistic history, it is striking how overwhelmingly negatively both of them were viewed at the time, with reporters predicting not only scandals outside of the ring but the demise of the sport of boxing altogether. In addition to reporters, various other players were also involved in trying to make sense of the transnational sporting culture. Finnish boxing aficionados were not only familiar with contemporary heavyweight championship bouts but the history of heavyweight boxing, while the athletes took an active role in shaping events, including the racialization processes. The ways in which multiple agents participated in the latter underscores the ListonAli heavyweight bouts as multidirectional racial projects, which served the purposes of 1960s boxing as de facto transnational sporting culture. Considering the complex network of individuals involved in these sporting events, transnational sporting culture itself might best be described as a labyrinthine nexus, with simultaneous and coexisting processes taking place on various scales on both sides of the Atlantic. 